http://revped.ise.ro

Print ISSN 0034-8678; Online ISSN: 2559 - 639X

\title{
EDUCATION OF PEOPLE WITH DISABILITIES. VISIONS, POLICIES AND CURRICULUM
}

EDUCAȚIA PERSOANELOR CU DIZABILITĂȚI. VIZIUNI, POLITICI ȘI CURRICULUM

\section{Traian VRĂSMAȘ}

\author{
Journal of Pedagogy, 2018 (1), 25 - 45 \\ https://doi.org/10.26755/RevPed/2018.1/25
}

The online version of this article can be found at: http://revped.ise.ro/category/2018-en/

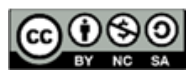

This work is licensed under the Creative Commons Attribution-NonCommercial-ShareAlike 4.0 International License.

To view a copy of this license, visit http://creativecommons.org/licenses/by-nc-sa/4.0/ or send a letter to Creative Commons, PO Box 1866, Mountain View, CA 94042, USA

Published by:

\section{InSTITUTUL DE ȘTIINȚE ALE EDUCAȚIEI}

http://www.ise.ro/

Further information about Revista de Pedagogie - Journal of Pedagogy can be found at:

Editorial Policy: http://revped.ise.ro/editorial-policy/

Author Guidelines: http://revped.ise.ro/the-writer-guide-2/ 


\title{
EDUCA IA PERSOANELOR CU DIZABILITĂ I. VIZIUNI, POLITICI ŞI CURRICULUM
}

\author{
Traian Vrăsmaş* \\ Universitatea „Ovidius” din Constan a, Facultatea de \\ Psihologie şi Ştiin ele Educa iei \\ Constan a, România \\ traianvrasmas@gmail.com
}

\section{Rezumat}

Educa ia persoanelor cu dizabilită i preocupă tot mai mult Europa şi întreaga lume, ca atare abordarea comparativă cu situa ia din România este necesară. Studiul trece în revistă principalele viziuni adoptate de societate, diacronic şi sincronic (modelul medical, social si biopsihosocial, abordarea categorială şi noncategorială), insistă asupra evolu iei comune a viziunilor, terminologiei şi politicilor educa ionale în acest context, eviden iază conexiunea cu evolu ia politicilor curriculare. În prezent, viziunea de necontestat a drepturilor umane (egalitate şi echitate, prin egalizarea şanselor) conduce la focalizarea tot mai mult a politicilor pe o abordare individualizată (personalizată) şi mai pu in pe una categorială, privitor la educa ia şi fundamentarea curriculumului şcolar la copiii/elevii cu dizabilită i. Un decalaj constatat al României, din acest punct de vedere - fa ă de alte ări din spa iul euroatlantic, chiar fa ă de unele ări vecine - ne responsabilizează în adoptarea unor măsuri, pe termen scurt şi mediu, posibile în actualul context legislativ, din perspectivă educa ională.

Cuvinte-cheie: dizabilitate, egalitate şi echitate, educa ie incluzivă, individualizare.

\begin{abstract}
The education of persons with disabilities is concerning progressively Europe and the entire world, which is why a comparative approach with Romanian situation is needed. The study reviews the main visions, in a diachronic and synchronic manner (the medical, the social and the bio psychosocial model,
\end{abstract}

* Prof. univ. dr., Universitatea „Ovidius” din Constan a. 
categorical and no categorical approach), insists on the common evolution of visions, terminology and educational policies in this context, emphasis the connection with curricular policies. At present the indisputable vision of human rights (equality and equity, through the equalisation of opportunities) leads to a progressive focus of policies on an individualised (personalised) approach and less on a categorical one, regarding the education and the fundaments of the school curriculum for children/pupils with disabilities. An identified procrastination of Romania from this point of view - comparing with countries from Euroatlantic space and even some neighbouring countries - makes us responsible for adopting some measures, on short and medium terms, which are possible in the actual legislative context, from the educational perspective.

Keywords: disability, equality and equity, inclusive education, individualisation.

\section{Introducere şi context}

În istoria umanită ii, copiii şi, în general, persoanele cu dizabilită i (handicap) au fost cel mai adesea marginalizate şi izolate de restul societă ii. Această atitudine dominantă a fost evidentă în toată lumea, până în anii ' 70 ai secolului XX şi până în anul 1989, în România. Societă ile au dezumanizat şi devalorizat frecvent persoanele cu dizabilită i (Peters, 1993). Esen a evolu iilor din lume după anul 1970 (la noi începând din anul 1990), prin multiple evenimente, documente şi dezvoltări de referin ă, constă în recunoaşterea deplină a acestor persoane ca fiin e umane (egale în drepturi şi demnitate), cu toate implica iile care decurg de aici - inclusiv exercitarea integrală a dreptului la educa ie.

Problematica educa iei persoanelor cu dizabilită i preocupă tot mai mult lumea şi Europa. Ultimele decenii au relevat schimbări majore privind viziunea şi terminologia legată de aceste persoane, de exercitarea dreptului lor la educa ie, ca drept uman fundamental.

Dacă în lume, în perioada 1970-1990 viziunea educa ională pentru aceste persoane a fost educa ia lor integrată (necunoscută şi neaplicată atunci în România), în prezent, ca urmare a unor evolu ii ulterioare anului 1990, în pas cu mişcarea interna ională a educa iei pentru to i şi în acord mai ales cu Conven ia ONU din 2007 a persoanelor cu dizabilită i (ratificată în 2010 la noi), dreptul la educa ie pentru aceste persoane reprezintă dreptul la educa ie 
incluzivă. Viziunea, în strânsă legătură cu terminologia utilizată şi cu politicile publice au influen at, în mare măsură, şi curriculumul educa ional oferit în şcoli.

Defini ia actuală a dizabilită ii, la care aderăm, este cea din Conven ia ONU privind persoanele cu dizabilită $i$ (2007, ratificată prin Legea 221/ 2010): „Persoanele cu dizabilită i includ acele persoane care au deficien e fizice, mentale, intelectuale sau senzoriale de durată, deficien e care, în interac iune cu diverse bariere, pot îngrădi participarea deplină şi efectivă a persoanelor în societate, în condi ii de egalitate cu ceilal i” (Legea 221/2010, art. 1, Scop).

Educa ie incluzivă este o no iune amplu utilizată, cu numeroase defini ii şi interpretări, adesea cu elemente de confuzie, îndeosebi în raport cu educa ia integrată. După UNESCO (2009), educa ia incluzivă este un proces continuu care vizează să ofere educa ie de calitate pentru to i, respectând, în acelaşi timp, diversitatea şi diferitele abilită $i$ şi necesită $i$, caracteristici şi aşteptări de la învă are ale elevilor şi comunită ilor, eliminând toate formele de discriminare.

Obiectivele acestui studiu sunt:

- Analiza sintetică, diacronică şi sincronică a viziunilor şi politicilor interna ionale şi na ionale privind educa ia persoanelor cu dizabilită i;

- Analiza comparativă a politicilor mondiale şi na ionale cu privire la curriculumul şcolar oferit copiilor şi tinerilor cu dizabilită i.

\section{Viziuni, terminologie şi politici}

\subsection{Scurtă istorie}

De-a lungul timpului, marginalizarea şi subvalorizarea umană a persoanelor cu dizabilită i s-a manifestat în diverse modalită i: de la exterminare (în Sparta antică, dar şi în lagărele naziste) la măsuri treptate de ocrotire (în locuri izolate de comunitate) şi apoi de acordare a unei cetă enii par iale, reduse, prin apari ia şcolilor speciale, destinate doar acestor persoane (segregate).

Persoanele cu dizabilită i (handicap), cum le denumim astăzi, au fost etichetate 
în diverse moduri în istoria omenirii: infirmi, idio i, anormali, cretini, întârzia i, debili, oligofreni, moroni, deficien i, inadapta i. Remarcăm, cu amărăciune, că unii dintre aceşti termeni (de exemplu deficien $i$ ) sau al ii asemănători sunt încă prezen i în zilele noastre, în vocabularul unor oameni sau chiar a unor texte publicate.

Tema educa iei acestor persoane nu era prezentă pe agenda preocupărilor sociale de-a lungul istoriei umane, chiar dacă unii pedagogi de renume (Comenius, în Didactica Magna capitolul IX, Rousseau, Locke şi Pestalozzi) au avut o contribu ie semnificativă la pledoaria umanistă perenă, pentru educa ia tuturor copiilor.

Paradigma tradi iei de secole, legată de educa ie, a fost (mai ales pentru unii copii cu dizabilită i) cea de anormalitate educa ională - vizibilă în viziunea oficială şi în politicile şcolare a numeroase ări până la finalul anilor ' 60 din secolul trecut. Debutul preocupărilor institu ionale de educare a copiilor cu dizabilită i, prin apari ia primelor şcoli speciale destinate acestora - la finele secolului XVIII - şi apoi multiplicarea acestora a reprezentat un pas important în evolu ia atitudinii sociale fa ă de această categorie umană - o nouă etapă şi viziune, aceea a acordării cetă eniei reduse. Copiilor şi tinerilor în această situa ie li s-a permis accesul în şcoli - chiar dacă erau speciale - ceea ce, la vremea respectivă, a reprezentat un impuls însemnat în schimbarea treptată a atitudinii şi concep iei de ansamblu a societă ii. Dacă aceste persoane pot să înve e, atunci reprezintă şi ele o anumită valoare în societate, chiar dacă ele înva ă par ial şi incomplet - ca substan ă şi nivel de studii, comparativ cu semenii lor.

Domeniul psihopedagogic constituit odată cu dezvoltarea educa iei în şcoli speciale a căpătat - cu deosebire în secolul XX - diverse denumiri, cea mai răspândită fiind educa ia specială - special education (engl.), éducation speciale (fr.). UNESCO recomandă sintagma Special Needs Education (ISCED, 2007, 2011) - educa ia (învă ământul) cerin elor speciale.

\subsection{Modelul medical}

Modelul medical al dizabilită ii - edificat treptat odată cu apari ia şcolilor 
speciale la sfârşitul secolului XVIII - accentuează îndeosebi prezen a unei deficien e biologice şi în consecin ă a unei probleme doar a individului în cauză. Mediul, comunitatea şi societatea, în general, aveau (au) pu ine (sau deloc) tangen e şi responsabilită i. Modelul medical a influen at puternic viziunea, terminologia şi politicile din educa ia (învă ământul) persoanelor cu dizabilită i. Peters (1993) arăta că, potrivit modelului medical, unor oameni li se pune eticheta de bolnavi şi sunt separa i pe baza acestui diagnostic, în programe separate, unde ei pot deveni func ionali pentru un loc în societate; ca handicapa $i$ concentrarea este doar pe individ, cu neglijarea contextului. Un studiu OCDE din 1994 sublinia, astfel, că no iunile utilizate în educa ia specială de către anumite ări reflectă această viziune - învă ământ corectiv, de remediere, pedagogie curativă, defectologie. Studiul UNICEF din 2012 face conexiunea dintre politicile educa ionale şi viziunea (paradigma) istorică - din secolul XX - asupra dizabilită ii şi educa iei speciale din Europa Centrală şi de Est, respectiv defectologia - de inspira ie sovietică (fosta denumire a psihopedagogiei speciale şi în România, până în luna mai 1990) - viziune dominată puternic de modelul medical. Aşa cum arăta şi un alt studiu UNICEF (Ainscow, \& Haile-Giorgis, 1998) influen a modelului medical în determinarea etichetei pe care un copil o va primi, a fost foarte puternică.

Consecin e ale modelului medical:

- Concentrarea pe vindecare şi recuperare perpetuează acea viziune (desuetă) a dizabilită ii ca fiind ceva anormal, un defect;

- Copilul este etichetat ca fiind anormal, deficient, bolnav, cu tulburări, cu disfunc ii etc.;

- Specialiştii se concentrează în evaluare mai ales pe ceea ce este deficitar, diferit în minus, fa ă de norme şi standarde (tipice) de dezvoltare;

- Specialiştii se oferă să repare, remedieze, corecteze, recupereze copilul;

- Viitorul copilului este limitat şi se bazează pe capacitatea percepută la un moment dat, static, nu pe poten ialul integral şi dinamic de dezvoltare şi nici pe aşteptările unui mediu interactiv, stimulativ;

- Copiii cu dizabilită i nu sunt accepta i pentru cine şi ceea ce sunt, şi nici pentru ceea ce pot deveni.

Remanen a viziunii medicale asupra dizabilită ii poate fi remarcată şi în limbajul cotidian din actualitate. Iată câteva expresii semnificative în acest sens:

- Despre un copil cu dizabilitate (handicap): „Este bolnav, săracul”; „A, 


\section{dar el nu este sănătos”;}

- Despre un alt copil (comparativ cu un copil cu dizabilită i): „El este sănătos”; „Al meu nu suferă de nimic”;

- Despre starea (situa ia) de dizabilitate (handicap): „El/ea suferă de sindromul Down" (Vrăsmaş, 2015).

Având ca fundament această viziune medicală, politicile educa ionale nu au luat în seamă sistemul de învă ământ obişnuit (de masă) care nu a fost responsabilizat. Şcolile de masă au exclus în mod tradi ional (în toată lumea până în anii '70 ai secolului trecut) pe acei copii percepu i ca diferi i. Au fost create structuri şcolare separate, marginale (unită $i$ şcolare speciale), pentru cei care nu atingeau standardele de performan e şcolare aşteptate. A apărut şi s-a dezvoltat puternic, mai ales în primele şapte decenii ale secolului XX, un sistem educa ional paralel, de şcoli şi alte institu ii speciale, care nu avea vreo legătură prea semnificativă cu restul învă ământului. În România, de exemplu, unele asemenea institu ii speciale nu făceau parte din re eaua şcolară a învă ământului, până în anul 1990.

În concluzie, deşi modelul medical a reprezentat un pas înainte fa ă de viziunea anterioară din istoria omenirii, viziunea s-a dovedit treptat - mai ales în ultimele decenii ale secolului XX - a fi una îngustă, incompletă, insuficient corelată cu evolu ia treptată a ştiin elor socioumane, a drepturilor umane - îndeosebi după adoptarea de către ONU a Declara iei universale a drepturilor omului (1948) şi a unor evolu ii ulterioare, de după 1970.

\subsection{Modelul social şi biopsihosocial}

Modelul social a fost lansat în anii '70 ai secolului XX, odată cu emergen a, pe agenda comunită ii interna ionale, a problematicii dizabilită ii, a afirmării drepturilor umane ale acestor persoane. Această nouă viziune afirmă, în esen ă, un model bazat pe drepturile omului - drepturi şi şanse egale. Dizabilitatea reprezintă, după acest model, mai mult o construc ie socială, iar problemele (dificultă ile) nu sunt atât ale individului, cât ale societă ii, ale mediilor care nu reuşesc să le primească şi să se adapteze acestor persoane. Obstacolele sociale se leagă mai ales de atitudinile persoanelor fără dizabilită i, fa ă de aceste persoane. 
Unii autori numesc acest model şi al minorită ii (Olkin, 1999). Impedimente majore pentru orice grup minoritar sunt prejudecă ile şi discriminarea, izolarea socială, tratamentul inegal, dependen a economică, rata mare de neangajare în muncă, locuin e inferioare şi rată înaltă de institu ionalizare (Bicklen, 1988, citat în Olkin, 1999).

Provocări ale modelului social (Vrăsmaş, 2015):

- Schimbarea perspectivei dominant medicale, care stabileşte grani a normalită ii şi exclude persoanele cu dizabilită i, acceptarea lor ca fiind fiin e umane, deci normale;

- Provocare adresată abordării medicale ca defect, ceva ce trebuie corectat, remediat, recuperat;

- Educarea societă ii pentru a în elege că dizabilitatea este parte a experien ei umane normale, deoarece, într-un anume moment al vie ii sau în anumite situa ii, fiecare poate ajunge într-o situa ie de dizabilitate;

- Provocare adresată acelor defini ii date dizabilită ii, care conduc la limitarea dezvoltării copilului şi nu recunosc poten ialul şi capacită ile de evolu ie ori identitatea acestuia (Conven ia ONU din 2007, art. 3, h).

În prezent, pe fondul unei apologii generale a principiilor integrării, normalizării (vie ii), egalită ii de drepturi şi de şanse, cel al incluziunii, principii promovate în toată lumea după anul 1970 (după 1990 şi la noi) în majoritatea viziunilor şi politicilor legate de dizabilitate, deşi modelul medical mai este încă prezent, el este criticat, chiar şi de către exponen i ai lumii medicale. Pledoaria umanistă, guvernamentală şi civică oficială este, în prezent, pentru nevoia depăşirii acestuia de către modelul social şi/sau de către un model multidisciplinar şi multisectorial. Organiza ia Mondială a Sănătă ii (OMS) a dezvoltat şi promovat modelul bio-psiho-social (CIF, 2001, 2007). Acesta încearcă integrarea a două modele relativ opuse - cel medical şi cel social.

Model bio-psiho-social promovat de OMS este utilizat pentru a reda esen a integrării diverselor perspective ale func ionării umane, ca o sinteză asupra tuturor componentelor sănătă ii: din punct de vedere biologic, psiho-individual şi social. Atât func ionarea, cât şi dizabilitatea - ca şi întreaga devenire umană, de fapt - nu poate fi explicată, în prezent, decât în şi prin interac iunea individului uman cu mediul, cu factorii contextuali (mediul fizic şi, mai ales, cel socio-cultural). Contextul social şi, în particular, cel şcolar, cu multiplele 
sale aspecte (curriculum, rela ie pedagogică, climat psihosocial etc.) este aşadar extrem de important în identificarea şi solu ionarea dificultă ilor din rela ia unui copil cu şcoala.

\subsection{Viziunea noncategorială versus cea categorială}

În educa ia (specială) a persoanelor cu dizabilită i, influen ată în bună măsură şi de paradigma medicală, au fost utilizate tradi ional - cu referire la serviciile sociale, dar şi la plasarea unor copii ca elevi în şcolile speciale - diverse categorii şi grade de dizabilitate. Categoriile de dizabilitate (handicap) stipulate de pildă la noi, în prezent (Legea 448/2006, art. 86), sunt: handicap fizic, vizual, auditiv, surdocecitate, somatic, mintal, psihic, HIV/SIDA, asociat, boli rare. Potrivit aceleiaşi legi, gradele de handicap sunt: uşor, mediu, accentuat şi grav.

Viziunea noncategorială în educa ia specială (foarte pu in cunoscută în ara noastră) - după unii autori crosscategorială sau multicategorială - a fost lansată în lume în anii '70. În esen ă, potrivit acestei viziuni asupra educa iei persoanelor cu dizabilită i, se consideră că împăr irea pe diverse grupuri (tipuri) de dizabilită i nu ajută prea mult educa ia şi interven ia, ea are şi dezavantajul de a eticheta (stigmatiza) un copil sau o persoană.

În controversa cu viziunea clasică - categorială - deocamdată viziunea noncategorială pare a fi preferată, mai ales privitor la deciziile legate de eligibilitatea pentru diverse servicii, de abilitare-reabilitare (Wheldall, 1994). Viziunea noncategorială consonează mai bine (decât viziunea clasică, categorială) cu dezideratul incluziunii educa ionale şi are ca implica ie importantă accentuare a nevoii de abordare individualizată, personalizată. D. Mitchell (2015) consideră că una dintre căile de depăşire a barierelor educa iei incluzive în lume este îndepărtarea sistemelor de categorisire. Multe sisteme legislative din lume se distan ează de utilizarea testării psihometrice şi de categorisire a elevilor prin abilitate/dizabilitate. Exemple de asemenea ări sunt Suedia, Sco ia, Danemarca, Norvegia, Anglia - cu excep ia celor cu dizabilită i profunde - şi Portugalia (EADSNE, 2012). 
2.5. Legisla ie, viziuni şi terminologie în România

În ara noastră a existat o perioadă - a anilor ' 80 din secolul trecut - în care abordarea, în general, a problematicii deficien elor (cu termenul promovat atunci, mai ales pentru copii în nevoie de ocrotire) era invizibilă în legisla ie, politici publice ori publica ii. Viziunea de bază era (în perioada 1970-1990), cea a nivelului (gradului) de recuperabilitate, model dominat clar de componenta biologică şi medicală.

O lege din anul 1970, (Legea nr. 3 privind ocrotirea unor categorii de minori), men inută în vigoare până în anii ' 90 , era bazată pe viziunea recuperabilită ii. Se interzicea unor copii cu deficien e dreptul la educa ie, prin catalogarea lor ca fiind irecuperabili, singura solu ie fiind la vremea aceea doar căminelespital. Al i copii cu dizabilită i aveau (relativ) mai multe şanse de devenire umană şi socială, prin încadrarea în categoria par ial recuperabili (cu plasarea în cămine-şcoală). Al ii erau într-o situa ie şi mai favorabilă - prin categorisirea drept recuperabili care le permitea accesul la grădini e şi şcoli speciale. Anii ' 90 au fost martorii adoptării, în România, a primelor legi cu privire la persoanele handicapate.

Legile postdecembriste (din anul 1992) au lansat ca no iune de baza persoana handicapată. Două Hotărâri de Guvern din 1990 introduseseră deja în legisla ie şi termenul de handicapat. Aceste două formule (handicapat şi persoană handicapată) au circulat, oficial, în toată perioada anilor ' 90 , dar şi al i termeni: deficien a şi handicapul.

Pentru şcolile speciale, aşa cum este stipulat la anexa nr. 3 a HG nr. 1161/ 1990, denumirea unei unită işscolare are, la final, formula pentru deficien $i$ (grădini e, şcoli etc). Privitor la curriculum, denumirea utilizată în planurile de învă ământ şi programele şcolare adoptate în anul 1993, prin negociere între Secretariatul de Stat pentru Handicapa i (SSH) şi Ministerul Învă ământului a fost aceea de copii/elevi cu handicap. În cadrul SSH a func ionat, din luna noiembrie 1990, Institutul na ional pentru recuperare şi educa ie specială a persoanelor handicapate ${ }^{1}$ (înfiin at, ini ial, în subordinea Ministerului Învă ământului, în luna mai 1990, cu denumirea de Centrul metodologic pentru recuperarea copiilor şi tinerilor handicapa i). 
Legisla ia şi terminologia s-au schimbat în anul 1999 (prin OUG nr. 102), adoptându-se sintagma persoane $c u$ handicap, în locul celei de persoane handicapate. Expresia persoane cu handicap va fi utilizată în aproape toată legisla ia ulterioară, inclusiv în Constitu ia din anul 2003 (în care art. 50 este intitulat Protec ia persoanelor cu handicap). Deşi poate părea minoră, modificarea din persoane handicapate în persoane cu handicap este una importantă, o nouă viziune de valorizare umană mai adecvată, de mai bună protejare a demnită ii. După anul 2000 a apărut, în legisla ia de la noi cumva ca o no iune alternativă la handicap - şi termenul de dizabilitate. În anul 2010, Parlamentul României a ratificat Conven ia ONU din 2006 (2007) privind persoanele cu dizabilită $i$ - deci a fost preluată într-o lege (nr. 221/2010) noua denumire - dizabilitatea. In anul 2011 dizabilitatea a intrat ca înlocuitor al handicapului în Legea asisten ei sociale (Legea nr. 292 din 2011). Din anul 2014 denumirea direc iei de specialitate din cadrul Ministerului Muncii, Familiei, Protec iei Sociale şi Persoanelor VârstniceDirec ia protec ia persoanelor cu dizabilită $i$ (potrivit HG nr. 344 din 30 aprilie 2014). În anul 2016 a fost adoptată o importantă Strategie na ională pentru persoane cu dizabilită $i$, asupra căreia vom reveni. În luna decembrie 2016 s-a ajuns la o denumire relativ comună (intersectorială) agreată de trei ministere şi care încearcă să delimiteze cumva rela iile dintre dizabilitate şi CES - dizabilitate şi/sau cerin e educa ionale speciale (ORDIN 1985/1305/5085 din 2016) asupra căreia nu putem insista aici, dar sintagma consonează cu concluziile unui studiu UNICEF-ISE-RENINCO (Educa ie pentru to $i$ şi pentru fiecare, 2015-2016).

În concluzie, în legisla ie, ca şi în literatura de specialitate, perioada ultimelor trei decenii a fost una foarte dinamică, cu referire la viziunile, legisla ia şi terminologia acestui domeniu. Concep iile şi terminologia s-au succedat sau coexistă, în legisla ie, politici publice sectoriale etc. În prezent, circulă, mai ales, termenii de handicap şi dizabilitate (cu semnifica ie echivalentă), cu o tendin ă vizibilă de înlocuire a handicapului cu dizabilitatea. Sunt sesizabile, de asemenea, unele diferen e între no iunile utilizate în sfera educa ională, socială şi de protec ie a copilului, de sănătate etc. Experien a directă a autorului, de circa 25 de ani, în grupuri de lucru interministeriale şi multidisciplinare, în diverse ipostaze (guvernamentală, neguvernamentală, academică) poate constitui o mărturie. Nu intră în economia acestui articol analiza no iunii de cerin e educa ionale speciale, reflectată în legisla ie şi 
practici, făcută în alte ocazii (E. Vrăsmaş, Manea, \& T. Vrăsmaş, 2014; Vrăsmaş, 2015). Aderăm la formula terminologică recentă de copii cu dizabilită $i$ şi/sau CES, care corespunde şi realită ii investigate prin cercetări recente în şcoli de masă (UNICEF, ISE, RENINCO, 2015-2016). Utilizăm în continuare, însă, termenul de dizabilitate.

\section{Curriculumul şcolar}

3.1. Perspectiva interna ională. Surse teoretice

Fundamentarea problematicii curriculare pentru elevii cu dizabilită i s-a bazat, în anii '70 (când comunitatea interna ională a devenit mult mai sensibilă la acest subiect), pe un model al dezvoltării, apărut în SUA, după adoptarea unei legi importante (PL94-142 din anul 1975), care statua dreptul tuturor copiilor cu dizabilită i de a beneficia de o educa ie publică gratuită şi adecvată (Mitchell et al., 2010; Mitchell, 2015). În esen ă, acest model sugera con inuturi curriculare adecvate nivelului de dezvoltare a unor copii/elevi.

La finele anilor '80, în construc ia curriculară a devenit dominant modelul func ional, care presupunea focalizarea pe abilită ile adecvate unei anumite vârste, pentru a putea func iona în via a comunită ii. De aici a apărut şi ideea Planului Educa ional Individual - obligatoriu în SUA, pentru elevii cu dizabilită i (ca şi în numeroase ări europene).

Al treilea model (după autorii mai sus cita i) cel actual - denumit aditiv reflectă includerea elevilor cu dizabilită i în clasele (şi curriculumul) şcolii generale - cu accent pe proiectarea centrată pe persoana care înva ă. Modelul se referă, deci, la modalită ile prin care elevii cu dizabilită i pot accesa şi participa la curriculumul educa iei generale.

Viziunea de actualitate privind natura curriculumului pentru elevi cu dizabilită i este, aşadar, una bazată pe drepturile umane, a egalită ii de acces, dar şi a echită ii, în sensul egalizării şanselor de participare la curriculumul general, prin variate maniere de accesibilizare şi flexibilizare curriculară: diferen iere (UNESCO, 2004), adaptare, modificare, adi ionare (de discipline compensatorii) etc. În prezent, există un acord larg şi adeziune în lume, 
privitor la principiul utilizării, la copiii şi tinerii cu dizabilită i, a contextelor educa ionale generale (incluzive) şi a con inuturilor curriculare corespunzătoare acestora (UNESCO, 2009, Jackson et al., 2010).

Accesul la curriculumul general şi accentuarea abordării individualizate (personalizate) sunt, de asemenea, tot mai evidente în documente interna ionale de dată relativ recentă.

UNICEF aprecia, în studiul din 2012, că pentru elevii cu dizabilită i se recomandă un ,curriculum comun, cel accesibil tuturor elevilor”, bazat pe o ,,instruire diferen iată şi/sau individualizată, mai degrabă decât un curriculum alternativ, pentru cei cu rezultate mai scăzute" (p. 13). Consiliul ONU pentru drepturile omului (OHCHR) stipula, într-un studiu tematic din 2013, că ,aten ia individualizată este o caracteristică centrală a educa iei incluzive" (E 46). Elementul de bază al unui plan educa ional individualizat este implicarea profesioniştilor, părin ilor şi elevilor (E 47).

Un document important din luna septembrie 2016 a fost adoptat de Comitetul ONU pentru drepturile persoanelor cu dizabilită i şi este dedicat comentării pe larg a aplicării art. 24 - referitor la educa ie - din Conven ia ONU 2007 a persoanelor cu dizabilită i. Urmează unele extrase şi comentarii relevante:

- Articolul 24: Dreptul la educa ie incluzivă

„Focalizarea este pe capacită ile şi aspira iile celui care înva ă, mai degrabă decât pe con inut, atunci când se planifică activită i de predare" (p. 5);

„Sistemul educa ional trebuie să furnizeze un răspuns educa ional personalizat, mai degrabă decât să aştepte ca elevul să se conformeze sistemului" (p. 5);

- Comentariu la paragraful 2 (a) - al articolului 24 din Conven ia ONU 2007, care urmează ,2 a) persoanele cu dizabilită $i$ nu sunt excluse din sistemul educa ional pe criterii de dizabilitate, iar copiii cu dizabilită $i$ nu sunt excluşi din învă ământul primar gratuit şi obligatoriu sau din învă ământul secundar, din cauza dizabilită ii”;

- Comentariu: „Paragraful 2 (a) interzice excluderea persoanelor cu dizabilită i din sistemul educa ional general, inclusiv orice legisla ie sau acte normative care limitează incluziunea lor, pe baza deficien ei sau a gradului acesteia" (p. 7); 
- Comentariu la paragraful 2 (e) - în continuare: „2 e) se iau măsuri eficiente de sprijin individualizat în amenajarea mediului care să maximizeze progresul şcolar şi socializarea, în conformitate cu obiectivul de integrare deplină";

- Comentariu: „Paragraful 2 (e) solicită furnizarea directă a unui sprijin continuu personalizat. Comitetul accentuează necesitatea asigurării planurilor educa ionale individualizate, care pot identifica adaptările rezonabile şi măsurile specifice de sprijin necesare pentru un anumit elev, inclusiv furnizarea unor mijloace asistive compensatorii, a unor materiale specifice de învă are, în formate alternative/accesibile, moduri şi mijloace de comunicare, auxiliare de comunicare şi tehnologie asistivă şi de informare" (p. 11).

În toamna anului 2017 a fost lansat un raport al Parlamentului European, care men ionează că dezvoltarea educa iei incluzive în Europa este înrădăcinată în dezvoltarea unei învă ări personalizate şi a unei predări flexibile (p. 37).

3.2. Legisla ia privind curriculumul formal pentru elevi cu dizabilită i din spa iul euroatlantic

În investiga ia noastră (Vrăsmaş, 2017) au fost selectate ările despre care a fost disponibilă informa ie de tip Elearning, pe această temă (în limba engleză, franceză, română). O sursă de bază în documentare a constituit-o site-ul organiza iei European Agency for Special Needs and Inclusive Education - EASNIE (Agen ia Europeană pentru Cerin e Speciale şi Educa ie Incluzivă), care con ine numeroase publica ii anuale şi câte o pagină dedicată fiecărui membru (fără România) (https://www.european-agency.org). ările investigate au fost: Anglia, Austria, Canada, Danemarca, Finlanda, Fran a, Irlanda, Islanda, Italia, Letonia, Moldova, Norvegia, Polonia, Portugalia, Sco ia, Serbia, Slovacia, SUA, Suedia, ara Galilor, Ungaria. Deşi studiul nostru comparativ a cuprins doar 21 de ări a rezultat cu destulă claritate, care sunt tendin ele din politicile şcolare, legate de curriculumul pentru elevi cu dizabilită i.

Formula de proiectare curriculară cea mai utilizată, în majoritatea acestor ări este Planul (Programul) Educa ional Individual (PEI). Mitchell et 
al. (2010) au identificat - la data studiului lor (foarte citat în plan interna ional) - 199 de referin e la acesta, dintre care 124 în SUA (prima ară care a introdus PEI, în 1975) şi 75 din afara SUA - mai ales din Europa. Un studiu din 2016 (Alkahtani et al.) analizează politicile educa ionale privitoare la PEI din 6 ări ale lumii: Australia (Queen Island), Canada (British Columbia), Noua Zeelandă, Marea Britanie, SUA şi Arabia Saudită.

Din cele 21 de ări investigate de noi, în 17 se prevede prin legisla ie Planul Educa ional Individual, desigur cu nuan ări în anumite ări: Plan personalizat în Fran a şi Canada, Program individual educa ional şi terapeutic în Polonia, Plan coordonat de sprijin în Sco ia, Plan de ac iune în Suedia, Plan individual de dezvoltare în ara Galilor.

Raportarea PEI (sau a altor forme de proiectare individualizată) se face, de regulă, la curriculumul na ional, accesibil tuturor elevilor de o anumită vârstă. PEI este proiectat pentru fiecare copil/elev cu dizabilită i, pentru a-i permite un acces şi progres şcolar cât mai bun.

Tranzi ia spre modelul noncategorial şi debutul proiectării curriculare individualizate este vizibilă şi în unele dintre fostele ări socialiste, din blocul sovietic (mai ales în Letonia, Polonia şi Slovacia) - precum şi în ări în curs de aderare la Uniunea Europeană (Moldova şi Serbia) - toate acestea fiind anterior inspirate, până în anii ' 90 , ca şi România, de paradigma defectologiei (Vrăsmaş, 2017). Ideea de sprijin (suport) pentru învă are, în general în şcoli, este prezentă în mod consistent în legisla ia ărilor investigate.

3.3. Situa ia din România privind curriculumul de învă ământ special şi alte forme de proiectare a serviciilor şi interven iei pentru copii cu dizabilită $\mathrm{i}$

Până la reforma curriculară din 1998, în învă ământul special² din ara noastră se utilizau planuri de învă ământ (şi programe şcolare) proiectate pe tipuri şi grade de dizabilitate (handicap), ca şi pe niveluri de învă ământ - preşcolar, primar, gimnazial, liceal, profesional, postliceal. Aceste planuri ca şi programele şcolare adiacente au fost elaborate în perioada 1992-1993, în cadrul sectorului de curriculum al Institutului Na ional pentru Recuperare şi Educa ie 
Specială a Persoanelor Handicapate. Focalizarea planurilor de învă ământ la acea dată pe tipul şi gradul de handicap era legată de tradi ia defectologică, impusă ulterior şi de Legea Învă ământului (1995, art. 44), ca şi de viziunea legisla iei specifice privind aceste persoane, adoptată în anul 1992. După anul 2002, apar - impulsionate de UNICEF şi autorită ile de protec ia copilului - noi forme de proiectare a serviciilor şi interven iei pentru copii cu dizabilită i (handicap): Planul de Servicii Personalizat (PSP) şi Planul de Interven ie Personalizat (PIP).

Planurile de învă ământ şi programele şcolare pentru învă ământul special, aprobate de MEN în anul 2005, sunt construite tot pe baza gradului de dizabilitate - textual al deficien ei - pe două categorii: a) deficien e moderate şi uşoare şi b) deficiente grave, severe, profunde sau asociate. Pentru clasa pregătitoare de învă ământ special a fost aprobat (în 2012) un nou plan de învă ământ - elaborat tot în maniera categorială, pe cele 2 grade mai sus men ionate, cu deosebirea că apare dizabilitatea în locul deficien ei, iar la punctul b) lipseşte gradul grav.

Referin a relevantă din Legea Educa iei Na ionale (nr. 1/2011, sec iunea 13, „Învă ământul special şi special integrat”, art. 48-52) pentru problematica de curriculum este: ,Învă ământul special dispune de planuri de învă ământ, de programe şcolare, de programe de asisten ă psihopedagogică, de manuale şi de metodologii didactice alternative, adaptate tipului şi gradului de dizabilitate" (art. 53). În 2016 au apărut 2 forme (aparent) noi de proiectare a interven iei pentru copii cu dizabilită i, cu denumirea de plan de abilitarereabilitare a copilului cu dizabilită $i$ şi planul de servicii individualizat.

Comentarii: Dacă în anul 1995, la adoptarea Legii Învă ământului situa ia în Europa şi în lume cu privire la problematica curriculară la elevi cu dizabilită i - şi cu atât mai mult în România - era în schimbare şi tranzi ie, spre modelul actual al dreptului şi şanselor egale la curriculumul general, în anul 2011 situa ia şi tendin ele interna ionale erau deja conturate. $\mathrm{Cu}$ toate acestea, prevederea din art. 53 a LEN din 2011 este cvasi-identică cu cea din 1995 (singura modificare fiind dizabilitatea în locul handicapului). Men inerea focalizării categoriale, pe tip şi grad de handicap (dizabilitate) este cumva justificată de natura legisla iei generale a dizabilită ii (handicapului) din România după anul 1990, respectiv acordarea serviciilor şi presta iilor sociale 
conform Legii nr. 448/2006, care stipulează la art. 85 că drepturile (compensatorii spunem noi) ale acestor persoane se acordă ,,pe baza încadrării în grad de handicap, în raport cu gradul de handicap".

Din perspectiva psihopedagogică, însă, men inerea focalizării curriculumului educa iei şcolare pe tipul şi gradul de dizabilitate (handicap) în LEN 2011 este mai greu de justificat, date fiind evolu iile men ionate deja, precum şi corelarea cu situa ia actuală din spa iul euroatlantic. În prezent, modelul care favorizează exercitarea drepturilor umane a persoanelor cu dizabilită i este modelul social, sau cel biopsihosocial, aşa cum recomandă numeroase organiza ii interna ionale, inclusiv clasificările de actualitate ale OMS (2001, 2007), viziune care ine seama nu doar de individ ci şi de context. Există semne de încurajare şi pentru schimbarea necesară la noi, ca de pildă Strategia na ională în derulare în România $O$ societate fără bariere pentru persoanele cu dizabilită $i$, 2016-2020, care face următoarea men iune cu privire la curriculum, în consonan ă cu dezvoltările din lume: ,Abordarea curriculumului pentru elevii cu dizabilită i din învă ământul special nu valorifică viziunea non-categorială, propusă de educa ia incluzivă” (p. 28).

\section{Concluzii şi recomandări}

Politicile educa ionale sunt strâns legate de viziunea şi terminologia adoptate în legisla ie şi determină, în mare măsură, managementul şi practicile efective dintr-un anumit sector de învă ământ, inclusiv legat de curriculum. Perioada celor peste 28 de ani consecutivi anului 1989 a fost, la noi, martora a numeroase apari ii de acte normative, atât în ce priveşte problematica generală a persoanelor cu dizabilită i, cât şi referitor la educa ia acestora. $\mathrm{Au}$ fost multe momente de avânt şi racordare la viziunile interna ionale (şi ele în schimbare), dar şi unele de stagnare şi iner ie.

Natura unui curriculum pentru elevi cu dizabilită i este determinată azi, în lume (ar trebui să fie şi la noi), de drepturile umane, de egalitatea de acces şi de echitate, în egalizarea şanselor de participare la curriculumul general, prin accesibilizare şi flexibilizare curriculară.

Designul individualizat al con inutului educa iei şcolare este - aşa cum am 
văzut din analiza interna ională - modalitatea de organizare curriculară recomandată de numeroase documente interna ionale şi practicată deja masiv în spa iul euroatlantic, introdusă recent chiar şi de unele ări vecine (Moldova, Serbia). Din cele prezentate rezultă cu claritate că tendin a majoră din politicile şcolare legate de curriculumul pentru elevi cu dizabilită i este elaborarea şi utilizarea unui Plan (Program) Educa ional Individual (PEI).

În ara noastră este sesizabilă remanen a modelului medical şi a paradigmei defectologice. La noi, legisla ia în vigoare men ine încă viziunea tradi ională, categorială asupra dizabilită ii (tipul şi gradul deficien ei ori dizabilită ii), inclusiv din punct de vedere al curriculumului şcolar. Această stare constituie - dacă se acceptă cu adevărat dezideratul şi viziunea educa iei incluzive - o serioasă barieră în calea dezvoltării unui învă ământ incluziv şi pentru acest grup de elevi. O mică exemplificare comparativă, în acest sens: ările din Europa care au adoptat explicit viziunea noncategorială asupra dizabilită ii (şi educa iei speciale) se numără şi printre cele mai avansate în promovarea efectivă a educa iei incluzive (Suedia, Danemarca, Norvegia, Sco ia, Portugalia).

Revizuirea modalită ii de bază a proiectării curriculum-lui pentru elevi cu dizabilită i - de la maniera categorială la cea individualizată (personalizată) necesită, desigur, o altă bază legislativă, atât din punct de vedere educa ional, cât şi în plan mai larg social şi este un proces pe termen lung. Se impune şi constatarea că, în ultimii ani, op iunea pentru educa ia incluzivă a copiilor cu dizabilită i este mai pu in evidentă la noi în politicile educa ionale (E. Vrăsmaş, T. Vrăsmaş, 2014, 2016).

Au apărut şi reac ii critice externe privind dorin a României de a consolida anumite forme de segregare (şcoli speciale), prin utilizarea unei terminologii mai acceptabile - centre şcolare de educa ie incluzivă (Consiliul Europei, 2017, p. 7).

Recomandări (pe termen scurt şi mediu, în limitele actualei legisla ii):

- O evaluare extinsă şi complexă, sub aspect legislativ si de implementare practică a sistemului educa ional în vigoare pentru copiii cu dizabilită i (şi/sau CES) din ara noastră, în contextul tendin ei generale spre incluziune educa ională;

- Institu ionalizarea unor grupuri de lucru complexe, dedicate educa iei 
(cerin elor) speciale, intersectoriale (cu diverse ministere), multidisciplinare, cu participarea ONG-urilor reprezentative şi a unor institu ii academice relevante;

- Evaluarea aprofundată a situa iei naturii curriculumului oferit de şcoli, a structurii şi eficien ei proiectelor educa ionale individualizate (ca şi a celor complementare) pentru copii/elevi cu dizabilită i, în spa iul euroatlantic;

- O cercetare evaluativă axată pe utilitatea şi eficien a actualelor planuri de învă ământ şi programe şcolare (categoriale), precum şi a altor forme de proiectare a sprijinului (de ex. PIP) pentru elevi cu dizabilită i, care înva ă în şcoli de masă sau în şcoli speciale din România;

- Implementarea unor proiecte-pilot, timp de un an de zile, în câteva şcoli din ară, a unui PEI (plan educa ional individual), pentru copii cu dizabilită i (handicap), atât în şcoli de masă cât şi în şcoli speciale.

\section{Note}

1. Acest institut a fost desfiin at în anul 2010.

2. De remarcat faptul că, deşi Legea nr.1/2011 este a Educa iei Na ionale, la sec iunea 13 denumirea este de învă ământ special şi nu de educa ie specială.

\section{Referin e}

- Ainscow, M., \& Haile-Giorgis, M. (1999). Educa ia copiilor cu cerin e speciale: Probleme şi perspective în Europa Centrală şi de Est. Innochenti Occasional Papers, Seria de politică economică şi socială. №67, 1998; traducere în limba română prin grija Reprezentan ei UNICEF în Romania, 1999.

- Alkahtani, M., \& Kheirallah, S. (2016). Background of Individual Education Plans (IEPs) Policy in Some Countries: A Review. Journal of Education and Practice, 7(24), 15-26. https://www.eric.ed.gov/?id=EJ1112737 7.08.2017.

- Consiliul Europei (2017, septembrie). Fighting school segregation in Europe through inclusive education: a position paper, https://rm.coe.int/fightingschool-segregationin-europe-throughinclusive-education-a-posi/ $168073 \mathrm{fb} 65$.

- European Agency for Special Needs and Inclusive Education - EASNIE / EADSNE (Agen ia Europeană pentru Cerin e Speciale şi Educa ie Incluzivă), 
https://www.european-agency.org.

- EADSNE. (2012). Mapping the Implementation of Policy for Inclusive Education, http://www.european-agency.org/sites/default/files/mipie-keypolicy-messages_MIPIE-policypaper-EN.pdf.

- Horga, I., Apostu, O., \& Balica, M. (2016). Educa ie pentru to $i$ şi pentru fiecare: accesul şi participarea la educa ie a copiilor cu dizabilită $i$ şi/sau CES din şcolile participante la Campania UNICEF Hai la şcoală!. Buzău, Alpha MDN.

- Hotărârea Guvernului Nr. 1161 din 1 noiembrie 1990, privind atribu iile, organizarea şi func ionarea Secretariatului de Stat pentru Handicapa i.

- Hotărârea Guvernului nr. 586 din 17 mai 1990, privind unele măsuri de îmbunătă ire a activită ii de ocrotire, instruire şi recuperare a copiilor şi tinerilor handicapa i şi a celor orfani.

- Jackson, L., B., Ryndak, D., L., \& Wehmeyer, M., L. (2008). The Dynamic Relationship Between Context, Curriculum, and Student Learning: A Case for Inclusive Education as a Research-based Practice. Research and Practice for Persons with Severe Disabilities, 34(1), 175-195. https:// doi.org/10.2511/rpsd.33.4.175.

- Legea Educa iei Na ionale, nr.1/2011, cu modificările şi completările ulterioare.

- Legea Învă ământului, 1995.

- Legea nr. 221 din 2010 pentru ratificarea Conven iei privind drepturile persoanelor $\mathrm{cu}$ dizabilită $i$, adoptată la New York de Adunarea Generală a Organiza iei Na iunilor Unite la 13 decembrie 2006, M.O. nr. 792 din 26 noiembrie 2010.

- Legea nr. 448/2006 privind protec ia persoanelor cu handicap, cu modificările şi completările ulterioare.

- Legea nr. 53/1992 privind protec ia specială a persoanelor handicapate.

- L'integration scolaire des enfants et adolescents handicapes: Ambitions, theories et pratiques, OCDE, Paris, 1994.

- Mitchell, D. (2015). Education that fits: review of international trends in the education of students with special educational needs, second edition. http://www.education.vic.gov.au/Documents/about/department/ psdlitreview_Educationthatfits.pdf.

- Mitchell, D., Morton, M., \& Hornby, G. (2010). Review of the Literature on Individual Education Plans. www.educationcounts.govt.nz /_data/assets/ pdf_file/0012/102216/Literature-Review-Use-of-the-IEP.pdf.

- Olkin, R. (1999). What Psychotherapists Should Know About Disability, New York, Guilford Press.

- OMS. (2004). Clasificarea Interna ională a func ionării, dizabilită ii şi sănătă ii (CIF), Organiza ia Mondială a Sănătă ii, în limba română cu sprijin UNICEF, MS, Bucureşti, Editura Marlink. 
- ONU. (2013). Thematic study on the right of persons with disabilities to education. Report of the Office of the United Nations High Commissioner for Human Rights (OHCHR), UN, Human Rights Council. http://www.rightto-education.org/sites/right-to-education.org/files/resource-attachments/ OHCHR_Study_RTE_Persons_with_Disabilities_2013.pdf.

- ONU. (2016). General comment No. 4, Article 24: Right to inclusive education. Committee on the Rights of Persons with Disabilities. September 2, 2016. http://www.refworld.org/docid/57c977e34.html.

- ORDIN 1985/1305/5085 publicat în M.F. nr. 1019/19.12.2016, privind aprobarea metodologiei pentru evaluarea şi interven ia integrată în vederea încadrării copiilor cu dizabilită i în grad de handicap, a orientării şcolare şi profesionale a copiilor cu cerin e educa ionale speciale, precum şi în vederea abilitării şi reabilitării copiilor cu dizabilită i şi/sau cerin e educa ionale speciale.

- Ordonan a de urgen ă nr. 102/1999 privind protec ia specială şi încadrarea în muncă a persoanelor cu handicap.

- Parlamentul European. (2017). Inclusive education for learners with disabilities. http://www.europarl.europa.eu/RegData/etudes/STUD/2017/596807/ IPOL_STU(2017)596807_EN.pdf.

- Peters, S. J. (ed.). (1993). Education and Disability in Cross-Cultural Perspective, Londra, Garland.

- UNESCO. (2004). Changing teaching practices. Using curriculum differentiation to respond to students diversity (http://unesdoc.unesco.org/ images/0013/001365/136583e.pdf).

- UNESCO. (2009). Policy Guidelines on Inclusion in Education, Paris, UNESCO. http://unesdoc.unesco.org/images/0017/001778/177849e.pdf.

- UNICEF. (2012). The Right of Children with Disabilities to Education: A Rights-Based Approach to Inclusive Education. Geneva, ATAR ROTO PRESSE SA.

http://www.inclusive-education.org/system/files/publications-documents/ UNICEF_Right\%20Children\%20Disabilities_En_WebACCESS.pdf.

- Vrăsmaş, E., Manea, L., \& Vrăsmaş, T. (2014). Studiu privind legisla ia referitoare la educa ia copiilor cu dizabilită i şi alte cerin e educa ionale speciale (CES) din perspectiva educa iei incluzive. Repere, Revistă de Stiin ele Educa iei, Vol. 8, nr. 1, pp. 7-20, Editura Universită ii din Bucureşti.

- Vrăsmaş, E., \& Vrăsmaş, T. (coord.). (2016). Cercetare privind modul în care cadrul legislativ şi practicile şcolare sprijină combaterea discriminării şi excluziunii sociale a copiilor cu cerin e educa ionale speciale, RENINCO şi FDP.

- Vrăsmaş, T. (2017). Curriculum categorial sau plan educa ional individual pentru elevii cu dizabilită $i$ ? COPED, 12-14.10.2017, Braşov. 
- Vrăsmaş, T. (2015). Cerin ele speciale şi dizabilitatea în educa ie. O perspectivă interna ională. Bucureşti, Editura Didactică şi Pedagogică.

- Vrăsmaş, T. (2013). Curriculum for children with disabilities in inclusive education. A literature review. PSIWORLD 2013, Procedia - Social and Behavioral Sciences, vol. 127, pp. 336-341. http://www.sciencedirect.com/ science/article/pii/S1877042814023581. https://doi.org/10.1016/j.sbspro. 2014.03.267.

- Wheldall, K. (1994). Why do contemporary special educators favor a noncategorical approach to teaching?. Special Education Perspectives, 3(1), 45-47.

The online version of this article can be found at: http://revped.ise.ro/category/2018-en/

\section{(c) DY-NC-SA}

This work is licensed under the Creative Commons Attribution-NonCommercial-ShareAlike 4.0 International License.

To view a copy of this license, visithttp://creativecommons.org/licenses/by-ncsa/4.0/ or send a letter to Creative Commons, PO Box 1866, Mountain View, CA 94042, USA.
Versiunea online a acestui articol poate fi găsită la:http://revped.ise.ro/category/2018-ro/

\section{(cc) BY-ne-sa}

Această lucrare este licen iată sub Creative Commons Attribution-NonCommercial-ShareAlike 4.0 International License.

Pentru a vedea o copie a acestei licen e, vizita $i$ http://creativecommons.org/licenses/by-nc-sa/4.0/ sau trimite i o scrisoare către Creative Commons, PO Box 1866, Mountain View, CA 94042, SUA. 